\title{
GEOGRAPHICAL CONSIDERATIONS REGARDING THE TOURIST INFORMATION AND PROMOTION CENTERS FROM BIHOR COUNTY, ROMANIA
}

\author{
Grigore Vasile HERMAN \\ University of Oradea, Department of Geography, Tourism and Territorial Planning, \\ University St., 410087, Oradea, Romania, e-mail: grigoreherman@yahoo.com \\ Tudor CACIORA \\ University of Oradea, Department of Geography, Tourism and Territorial Planning, \\ University St., 410087, Oradea, Romania, e-mail: tudor.caciora@yahoo.com

\section{Răzvan DUMBRAVĂ} \\ University of Oradea, Department of Geography, Tourism and Territorial Planning, \\ University St., 410087, Oradea, Romania, e-mail: razvid@gmail.com
}

Seedou Mukthar SONKO

Assane Seck University of Ziguinchor, Department of Tourism, Senegal, e-mail: sm.sonko@univ-zig.sn

\section{Zharas Galimzhanovich BERDENOV}

$\mathrm{PhD}$, Associate Professor of the Department of Physical and Economic Geography, L.N. Gumilyov Eurasian National University, Astana, Kazakhstan, e-mail: berdenov-z@mail.ru

\section{Ruslan Zairovich SAFAROV}

Candidate of chemical sciences, Associate Professor of the Department of Management and Engineering in the field of environmental protection, L.N. Gumilyov Eurasian national university, Kazakhstan, e-mail: ruslanbox@yandex.ru

\section{Mihaela UNGUREANU *}

University of Oradea, Department of Geography, Tourism and Territorial Planning, University St., 410087, Oradea, Romania, e-mail: umihaela59@yahoo.com

\begin{abstract}
Citation: Herman, G. V., Caciora, T., Dumbravă, R., Sonko, S. M., Berdenov, Z. G., Safarov, R. Z., \& Ungureanu, M. (2019). GEOGRAPHICAL CONSIDERATIONS REGARDING THE TOURIST INFORMATION AND PROMOTION CENTERS FROM BIHOR COUNTY, ROMANIA. GeoJournal of Tourism and Geosites, 27(4), 1439-1448. https://doi.org/10.30892/gtg.27427-446
\end{abstract}

\begin{abstract}
The present study aims to determine the role and importance of the tourist information and promotin centers from Bihor county taking into consideration the economic, social and cultural influence of tourism worldwide. These centers were established to provide tourists with the necessary and updated information regarding the tourist destination, thus to become a major part in the promotion of tourist attractions. The implemented methodology based on
\end{abstract}

\footnotetext{
* Corresponding author
} 
Grigore Vasile HERMAN, Tudor CACIORA, Răzvan DUMBRAVĂ, Seedou Mukthar SONKO,

Zharas Galimzhanovich BERDENOV, Ruslan Zairovich SAFAROV, Mihaela UNGUREANU

questionnaires helped us assess the role of these centers in the shaping of Bihor county tourist destination and the analysis of the existent web sites ( 8 out of 13 tourist centers have got one) gave us an insight into the significance of internet promotion as a powerful marketing tool of the 21st century.

Key words: tourist information and promotion centers, role and importance, tourist destination

\section{INTRODUCTION}

In the last two decades, tourism has emerged as a key factor for the worldwide economic development. Therefore, in 2011 it contributed with 9\% la to the global GDP and it involved 1 in every 12 workers on the planet (Shi \& Li, 2013), whereas for 2018 the figures were higher - $10.4 \%$ of the global GDP, 1 in 2 jobs being done in the tourism sector (WEF, 2019). The outstanding growth of tourism especially in the second half of the 2oth century and the beginning of the $21^{\text {st }}$ century is due to the fact that the public has had more access to the tourist products (Armenski et al., 2012). If in the year 1950, 25 million people travelled outside their countries of residence for tourist reasons, in 2011 their number rose to approximately 980 million (Dahiya \& Duggal, 2015), a sign that tourism is a sector in a constant growth and development. The tourist offer has also changed according to the considerable increase of the demand, on the tourism marked appearing a wide range of destinations (Ivanov \& Webster, 2013; Antonescu \& Stock, 2014) with varied offers and attractions. In a tourism industry which offers a variety of opportunities and in which only the best managed ones thrive, (Kayar \& Kozak, 2010), the key word is competitiveness (Andrades-Caldito et al., 2012; Leung \& Baloglu, 2013; Croes \& Rivera, 2010). As a result, each torist destination tries to take advantage of its own assets to attract the greatest number of visitors. Such an advatage could be a healthy tourist promotion, which can offer tourists precious information about the destination, influencing their decision-making process (Shi \& Li, 2013; Molina et al., 2010; Uysal, 2013). Alongside with the evolution and the individualisation of the human society as unrestricted regarding the free circulation of information, the limits of the tourist industry have extended continuously (Koo et al., 2015). Nowadays, understanding the way in which the information about tourism functions is vital, especially because recent studies in this field (Horng \& Tsai, 2010; Chaiprasit et al., 2011; Jeaon et al., 2011; Standing et al., 2014) show that the information sources have a great impact on the tourists' preferences. The conventional sources, such as the tourist information and promotion centers are partially responsible for the spread of tourist information.

The tourist information and promotion centers represent a dynamic vector of tourism with profound implications in the creation and promotion of the image of the tourist destination, playing a key role in the first impression created by the visitor regarding the destination (Chaşovschi et al., 2016; Herman et al., 2019; Lyu \& Hwang, 2015; Cox \& Wray, 2011). The creation of tourist destination image is a delicate process that requires considerable time and resouces. Besides the TIPC, other local and international factors take part in the creation of this image. Among them, we mention: the organizations for the management of the touris destination (OMD), The Ministry of Tourism (or similar structures), The Romanian Government through special institutions, the tourism agecies, the tourist service providers (accommodation, public food service, entertainment, recreation, treatment etc), public authorities (local, 
regional, national) and the local population. From the above mentioned reasons, it is clear that the action of creation of a tourist destination image is of large-scale due to the human factor involved and above all, because of the benefits it can create for the local community and for the global one indirectly (Li et al., 2017; Fyall et al., 2012; Mendola \& Volo, 2017; Sainaghi et al., 2017; Dwyer et al., 2014; Gómez-Vega \& Picazo-Tadeo, 2019; Mariani, 2014; Saarinen, 2001, 2004; Dela \& Aria, 2016; Więckowski et al., 2014; Lindner-Cendrowska, 2013; Toral et al., 2018). These are translated at local level by: the creation of a positive image for the tourist destination; the increase of the duration of the tourist stay; the development of new tourist planning sites; the rise of the social level; the development of local economy; the sustainable, responsible development of the territory; the preservation and protection of the environment etc.

The present study comes as a necessity to assess these centers responsible for the information dissemination and the role they play in the creation of the tourist destination image of Romania, in general (Bogan, 2014; Ilieș et al., 2018; Gozner et al., 2018; Lincu et al., 2018; Paicu \& Hristache, 2013), and of Bihor county in particular. Taking into account the $131^{\text {st }}$ place out of 136 studied countries where Romania was in the 2017 World Economic Forum report regarding the tourism competitiveness, marketing and branding efficiency to attract tourists, (WEF, 2017) the relevance of the study is the greater. Bihor county, situated "in the west part of Romania, right near Romania's state border with Hungary, at the contact between the morphological units of Tisa Plain (subunit of the Western Plain) with the Carpathian Mountains (The Occidental Carpathians), in the hydrographic basin of the Tisa River" (Herman et al., 2017), is represented by 13 TIPC located on the territory of 11 administrative units, in 11 localities (Table 1).

Tabel 1. The Tourist Information and Promotion Centers in Bihor County

\begin{tabular}{|c|l|l|l|}
\hline No. & \multicolumn{1}{|c|}{ TIPC name } & \multicolumn{1}{c|}{ TAU } & \multicolumn{1}{c|}{ Address } \\
\hline 1 & $\begin{array}{l}\text { Bihor National Tourist Information and } \\
\text { Promotion Center }\end{array}$ & Oradea & Str. Patrioților nr.2, Oradea \\
\hline 2 & $\begin{array}{l}\text { Oradea Town Hall Tower Tourist } \\
\text { Information Center }\end{array}$ & Oradea & Piața Unirii nr. 1-2, Oradea \\
\hline 3 & $\begin{array}{l}\text { Oradea Fortress Tourist Information } \\
\text { Municipal Center }\end{array}$ & Oradea & $\begin{array}{l}\text { Piața Emanuil Gojdu nr.41, corp J, } \\
\text { Oradea }\end{array}$ \\
\hline 4 & $\begin{array}{l}\text { Beiuș National Tourist Information and } \\
\text { Promotion Center }\end{array}$ & Beiuș & Calea Bihorului, Nr.28, Beiuș \\
\hline 5 & $\begin{array}{l}\text { Nucet National Tourist Information and } \\
\text { Promotion Center }\end{array}$ & Nucet & Str. Republicii nr.8, Nucet \\
\hline 6 & $\begin{array}{l}\text { Vașcău National Tourist Information } \\
\text { and Promotion Center }\end{array}$ & Vașcău & Str. Unirii, nr.75, Vașcău \\
\hline 7 & $\begin{array}{l}\text { Aleșd National Tourist Information and } \\
\text { Promotion Center }\end{array}$ & Aleșd & Str. Bobâlna, Nr.3, Aleșd \\
\hline 8 & $\begin{array}{l}\text { Bratca National Tourist Information and } \\
\text { Promotion Center }\end{array}$ & Bratca & Str. Principala, Nr.126, Bratca \\
\hline 9 & $\begin{array}{l}\text { Cărpinet National Tourist Information } \\
\text { and Promotion Center }\end{array}$ & Cărpinet & Str. Principala nr.8o, Cărpinet \\
\hline 10 & $\begin{array}{l}\text { Mădăras National Tourist Information } \\
\text { and Promotion Center }\end{array}$ & Mădăras & Str. Principala, Mădăras \\
\hline 11 & $\begin{array}{l}\text { Câmpani National Tourist Information } \\
\text { and Promotion Center }\end{array}$ & Câmpani & Str. Principala nr.1, Câmpani \\
\hline 12 & Vadu Crișului Tourist Information Center & Vadu Crișului & Str.Principală nr.693, Vadu Crișului \\
\hline 13 & Bulz Tourist Information Center & Bulz & Str. Principala nr. 134i, Bulz \\
\hline
\end{tabular}


The present study aims to highlight some quantitative and qualitative aspects related to the role and importance of tourist information and promotion centers, previously mentioned, in the shaping and promotion of Bihor county as a tourist destination. Bihor tourist destination is defined by the existence of four tourist resorts: (Băile Felix, Băile 1 Mai, Băile Tinca, Stâna de Vale) and eight areas of maximum concentration of tourist resources and the necessary infrastructure for their operation: Oradea, Băile Felix, Pădurea Craiului (including Valea Iadului), Stâna de Vale, Padiș, Vârtop, Câmpia Crișurilor (pseudodestination), Ierului Valley and Barcăului Valley.

\section{WORKING METHODOLOGY}

In the current study we used the social survey method based on questionnaire (Babbie, 2010; Bar et al., 2016; Bryman, 2012; Chelcea, 2007; Ilieş et al., 2015; Tătar et al., 2018a, 2018b, Herman et al., 2019a, b) and the websites analysis. The questionnaire used to obtain the data regarding the role and importance of information and promotion centers in the shaping and promotion of Bihor image as a tourist destination was administered in the time frame 01.10.2017 - 20.04.2018 and readministered in the period 01.11.2018 - 30.01.2019. Structurally speaking, the used questionnaire contained 10 items with reference to: tourist attractions; tourist promotion materials; accommodation infrastructure; access to public transport infrastructure; tourist guidance activity; events of tourism exhibitions; recommanded local tourist products; local tourist circulation; existence of tourist destinations and other defining aspects in the creation of the tourist destination image. The analysis of the centers' websites is a necessity as the internet has undoubtedly become the most powerful marketing instrument (Andreopoulou et al., 2014), with significant roles in the dissemination of information and promotion of tourism. Their analysis followed the same methodological pattern used during the sociological method of the questionnaire seeking to obtain answers to the 10 items mentioned above, from the content of the pages corresponding to TIPC Bihor. To quantify the responses received from the sociological survey and websites analysis, each of the 10 items was given a single value equal to 1, a proportion of $10 \%$ respectively. This value resulted from the summation of the given score of 0.5 for each typical category separately, questionnaire and websites analysis respectively at the level of each item (Table 1). Based on these values, a value scale was drawn up regarding the role of TIPC with ranges between 1 and 4 points (insignificant role); 5 and 6 points (minor role); 7 and 8 points (average role); 9 and 10 points (major role).

Regarding the quantity and quality of the obtained results, we have to state that the requested information, with the help of the questionnaire, is public information that the tourist information and promotion centers have the obligation to provide to anyone who requests it for free (Order 1096, 2008, para. 4.1), while according to the appendix 4 regarding the Basic Structue of the CNIPT specified in the Regional Operational Programme 2007-2013; Priority Axis 5 - Sustainable Development and Tourism Promotion; Major Intervention Field 5.3 - The Promotion of the Tourist Potential and the Creation of the Necessary Infrastructure to Increase Romania's Attractiveness as a Tourist Destination; Operation The Creation of the National Centers for Tourist Information and Promotion (CNIPT) and their equipment. This is public information that can be accessed from the web page corresponding to each tourist information and promotion center.

\section{RESULTS AND DISCUSSIONS}

Using the above mentioned methodology, 13 TIPC were questioned via the questionnaire method, out of which 10 centers followed that course of action. With regard 
to the websites analysis, 8 TIPC were assessed, the other 5 having no web or internet page. The integrated analysis of the obtained information has highlighted the existence of some major malfunctions regarding the possession of information with respect to the local tourist circulation, recommanded local tourist products, access to public transport infrastructure, tour guiding activity and other marked aspects for the creation of the tourist destination image, while a better situation was registered at the chapters regarding the tourist attractions, tourist promotion materials ans accommodation infrastructure (Table 2, Figure 1). From the perspective of each analysed parameter, it was noticed the existence of the following typical categories of indicators: with major role (1 indicator, Tourist attractions); with average role ( 2 indicators, Tourist promotion materials; Accommodation infrastructure); with very low role (4 indicators; Local tourist circulation; Tourists access to public transport infrastructure; Tour guiding activity; Tourist exhibitions; Recommended local tourist products; Other defining aspects in creating a tourist destination image; The existence of tourist destinations) (Table 3).

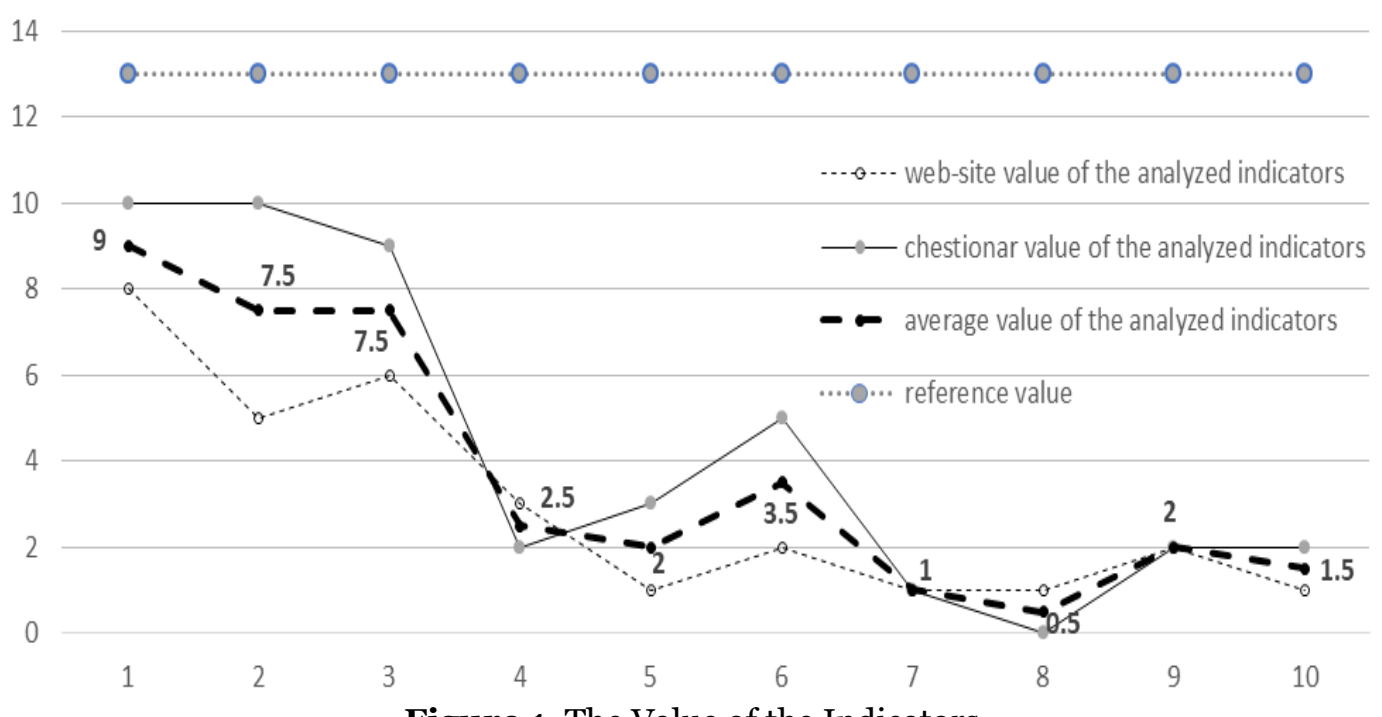

Figure 1. The Value of the Indicators

As a result of the quantification of the TIPC role and importance in the shaping of the Bihor county tourist destination image, according to the methodology developed in the present study, it is clearly noticeable that TIPC play an insignificant role (Table 2, 3, figure 2). This resuted from the quantification of the obtained score (37 points, 37\%) for each of the 10 analysed indicators, for the 13 assessed TIPC (1 point for each indicator, total 130 points). Bihor National Tourist Information and Promotion Center (major role) and Aleșd Tourist Information and Promotion Center (minor role) are exceptions from this rule (tabelul 3). Bihor National Tourist Information and Promotion Center obtained 9 out of 10 points, which placed it in the category of centers with major impact. From the analysis of the indicators taken into account in this study, a few malfunctins emerged regarding the recommended locat tourist products and the possession of information with respect to tourist circulation in the last 5 years.

Aleșd National Tourist Information and Promotion Center has a minor importance in the shaping and promotion of Bihor tourist destination obtaining 6 points. The individual study of each indicator, for Aleșd TIPC has highlighted a number 
Grigore Vasile HERMAN, Tudor CACIORA, Răzvan DUMBRAVĂ, Seedou Mukthar SONKO,

Zharas Galimzhanovich BERDENOV, Ruslan Zairovich SAFAROV, Mihaela UNGUREANU

of weak points regarding the tour guiding activity, recommended local tourist products, local tourist circulation and the existence of tourist destinations.

Tabelul 2. The value of the score obtained by TIPC in Bihor according

to the indicators used to quantify the role of the tourist information and promotion centers

\begin{tabular}{|c|c|c|c|c|c|c|c|c|c|c|c|c|c|}
\hline \multirow{2}{*}{ No. } & \multirow{2}{*}{ Centers } & \multicolumn{10}{|c|}{ Number of item analized } & \multirow{2}{*}{ Total } & \multirow{2}{*}{ Role } \\
\hline & & $\mathbf{1}$ & 2 & 3 & 4 & 5 & 6 & 7 & 8 & 9 & 10 & & \\
\hline 1 & $\begin{array}{l}\text { Bihor National Tourist } \\
\text { Information and } \\
\text { Promotion Center }\end{array}$ & 1 & 1 & 1 & 1 & 1 & 1 & 0.5 & 0.5 & 1 & 1 & 9 & Major \\
\hline 2 & $\begin{array}{c}\text { Turnul Primăriei Oradea } \\
\text { Tourist Information Center }\end{array}$ & $\mathrm{O}$ & $\mathrm{O}$ & $\mathrm{O}$ & $\mathrm{O}$ & $\mathrm{O}$ & $\mathrm{O}$ & $\mathrm{O}$ & $\mathrm{O}$ & $\mathrm{O}$ & 0 & $\mathbf{o}$ & Insignificant \\
\hline 3 & $\begin{array}{c}\text { Cetatea Oradea Tourist } \\
\text { Information Municipal Center }\end{array}$ & 0.5 & $\mathrm{O}$ & $\mathrm{O}$ & $\mathrm{O}$ & $\mathrm{O}$ & $\mathrm{O}$ & $\mathrm{O}$ & $\mathrm{O}$ & O & 0 & 0.5 & Insignificant \\
\hline 4 & $\begin{array}{l}\text { Beiuş National Tourist } \\
\text { Information and } \\
\text { Promotion Center }\end{array}$ & 1 & 1 & 1 & 0 & 0 & 0.5 & 0 & 0 & 0 & 0.5 & 4 & Insignificant \\
\hline 5 & $\begin{array}{l}\text { Nucet National Tourist } \\
\text { Information and } \\
\text { Promotion Center }\end{array}$ & 1 & 1 & 1 & 0 & $\mathrm{o}$ & $\mathrm{o}$ & 0 & 0 & 0 & 0 & 3 & Insignificant \\
\hline 6 & $\begin{array}{l}\text { Vașcău National Tourist } \\
\text { Information and } \\
\text { Promotion Center }\end{array}$ & 1 & 1 & 0.5 & 0.5 & 0 & $\mathrm{O}$ & 0 & 0 & 0 & 0 & $\mathbf{3}$ & Insignificant \\
\hline 7 & $\begin{array}{l}\text { Aleșd National Tourist } \\
\text { Information and } \\
\text { Promotion Center }\end{array}$ & 1 & 1 & 1 & 1 & $\mathrm{O}$ & 1 & 0 & 0 & 1 & 0 & 6 & Minor \\
\hline 8 & $\begin{array}{l}\text { Bratca National Tourist } \\
\text { Information and } \\
\text { Promotion Center }\end{array}$ & 0.5 & 0.5 & 0.5 & $\mathrm{O}$ & 0 & 0.5 & 0.5 & 0 & 0 & 0 & 2.5 & Insignificant \\
\hline 9 & $\begin{array}{l}\text { Cărpinet National Tourist } \\
\text { Information and } \\
\text { Promotion Center }\end{array}$ & 0.5 & 0.5 & 0.5 & 0 & 0.5 & $\mathrm{o}$ & 0 & $\mathrm{O}$ & 0 & 0 & 2 & Insignificant \\
\hline 10 & $\begin{array}{l}\text { Mădăras National Tourist } \\
\text { Information and } \\
\text { Promotion Center }\end{array}$ & 1 & 0.5 & 1 & $\mathrm{O}$ & 0.5 & $\mathrm{o}$ & $\mathrm{o}$ & $\mathrm{o}$ & o & 0 & 3 & Insignificant \\
\hline 11 & $\begin{array}{l}\text { Câmpani National Tourist } \\
\text { Information and } \\
\text { Promotion Center }\end{array}$ & 1 & 0.5 & 1 & 0 & $\mathrm{o}$ & 0.5 & $\mathrm{o}$ & $\mathrm{o}$ & 0 & 0 & $\mathbf{3}$ & Insignificant \\
\hline 12 & $\begin{array}{l}\text { Vadu Crissului Tourist } \\
\text { Information Center }\end{array}$ & $\mathrm{O}$ & 0 & 0 & $\mathrm{o}$ & $\mathrm{O}$ & $\mathrm{o}$ & $\mathrm{o}$ & $\mathrm{o}$ & o & 0 & $\mathbf{o}$ & Insignificant \\
\hline 13 & $\begin{array}{c}\text { Bulz Tourist } \\
\text { Information Center }\end{array}$ & 0.5 & 0.5 & 0 & 0 & 0 & 0 & 0 & 0 & 0 & 0 & $\mathbf{1}$ & Insignificant \\
\hline & TOTAL & 9 & $7 \cdot 5$ & $7 \cdot 5$ & 2.5 & 2 & $3 \cdot 5$ & $\mathbf{1}$ & 0.5 & 2 & 1.5 & $\mathbf{3 7}$ & Insignificant \\
\hline & Role & 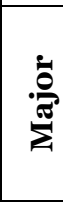 & 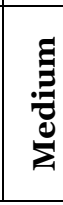 & $\underset{\Xi}{\Xi}$ & 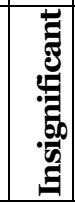 & 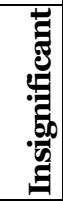 & 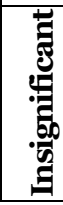 & 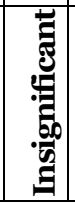 & 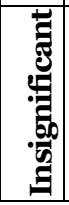 & 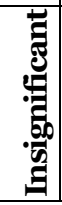 & 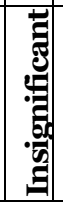 & 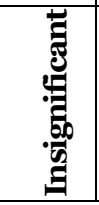 & \\
\hline
\end{tabular}

Although we can say that quantitatively the information materials were satisfactory in number, qualitatively, these do not emphasize the destination and are not updated, a lot of them being done when the center was established, as part of the 
project from which they emerged. Moreover, the materials are not unitary at the level of Bihor destination, each one being done based on different concepts. Other information is hardly available (regarding the transport infrastructure and public transport, tour guiding or local tourist circulation). This fact shows that there is no monitoring system at the level of Bihor destination. The centers' websites are not completely functional, and the majority of those that function, do not contain updated information.

To render efficient the activity of the tourist information centers it is necessary to create a tourist network and to identify its best communication channel. This network must have a (institutional) coordinator and must include all the factors interested in tourism at local and county level. It is essential to create a unitary communication channel with the beneficiaries at the network level and other new opportunities for the tourist development of the communities where the information centers operate.

Tabelul 3. The criteria used to quantify the role of torist information and promotion centers

\begin{tabular}{|c|c|c|c|c|c|c|c|c|}
\hline \multirow{3}{*}{$\begin{array}{l}\text { Nr. } \\
\text { crt. }\end{array}$} & \multirow{3}{*}{$\begin{array}{l}\text { Relevant criteria to assess } \\
\text { the role of the tourist } \\
\text { information and } \\
\text { promotion centers in the } \\
\text { creation of Bihor tourist } \\
\text { destination image }\end{array}$} & \multicolumn{3}{|c|}{ Nominal value } & \multicolumn{3}{|c|}{ Total value ${ }^{1}$} & \multirow{3}{*}{ TIPC role } \\
\hline & & \multirow{2}{*}{$\begin{array}{c}\text { Questi } \\
\text { onnaire } \\
\text { No. }\end{array}$} & \multirow{2}{*}{$\begin{array}{c}\text { Website } \\
\text { No. }\end{array}$} & \multirow{2}{*}{$\frac{\text { Ratio }}{\%}$} & \multirow{2}{*}{$\begin{array}{c}\text { Questi } \\
\text { onnaire } \\
\text { No. }\end{array}$} & \multirow{2}{*}{$\begin{array}{c}\text { Website } \\
\text { No. }\end{array}$} & \multirow{2}{*}{$\begin{array}{c}\text { Ratio } \\
\%\end{array}$} & \\
\hline & & & & & & & & \\
\hline 1 & Tourist attractions & 0.5 & 0.5 & 10 & 5 & 4 & 90 & Major \\
\hline 2 & $\begin{array}{l}\text { Tourist promotion } \\
\text { materials }\end{array}$ & 0.5 & 0.5 & 10 & 5 & 2.5 & 75 & Medium \\
\hline 3 & $\begin{array}{l}\text { Accommodation } \\
\text { infrastructure }\end{array}$ & 0.5 & 0.5 & 10 & 4.5 & 3 & 75 & Medium \\
\hline 4 & $\begin{array}{l}\text { Tourists access to public } \\
\text { transport infrastructure }\end{array}$ & 0.5 & 0.5 & 10 & 1 & 1.5 & 25 & Insignificant \\
\hline 5 & Tour guiding activity & 0.5 & 0.5 & 10 & 1.5 & 0.5 & 20 & Insignificant \\
\hline 6 & Tourist exhibitions & 0.5 & 0.5 & 10 & 2.5 & 1 & 35 & Insignificant \\
\hline 7 & $\begin{array}{l}\text { Recommended local } \\
\text { tourist products }\end{array}$ & 0.5 & 0.5 & 10 & 0.5 & 0.5 & 10 & Insignificant \\
\hline 8 & Local tourist circulation & 0.5 & 0.5 & 10 & $\mathrm{O}$ & 0.5 & 5 & Insignificant \\
\hline 9 & $\begin{array}{l}\text { Other defining aspects } \\
\text { in creating a tourist } \\
\text { destination image }\end{array}$ & 0.5 & 0.5 & 10 & 1 & 1 & 20 & Insignificant \\
\hline $\begin{array}{l}1 \\
0\end{array}$ & $\begin{array}{l}\text { The existence of tourist } \\
\text { destinations }\end{array}$ & 0.5 & 0.5 & 10 & 1 & 0.5 & 15 & Insignificant \\
\hline & Total & 5 & 5 & 100 & 22 & 15 & 37 & Insignificant \\
\hline
\end{tabular}

The information centers network must facilitate the access to a complete and integrated set of information across the county, regarding the tourist destinations, tourist attractions, tourist services, including accommodation, support and working facilities. By enhancing such a network, we could improve the tourists' information and even satisfaction level, including tourist loyalty of all who travel in Bihor county.

\section{CONCLUSIONS}

The analysis of the tourist information centers from Bihor county (13 centers),

\footnotetext{
${ }^{1}$ Valoare totală 130 puncte (1 punct pentru fiecare criteriu aferent celor 13 centre de informare și promovare turistică analizate)
} 
Grigore Vasile HERMAN, Tudor CACIORA, Răzvan DUMBRAVĂ, Seedou Mukthar SONKO, Zharas Galimzhanovich BERDENOV, Ruslan Zairovich SAFAROV, Mihaela UNGUREANU

using the methodology developed during the present study, has illustrated that these institutions have an insignificant importance at county level, except for Bihor National Tourist Information and Promotion Center (major importance) and Aleșd National Tourist Information and Promotion Center (minor importance). The analysis of these centers at item level has highlighted the existence of some serious problems at almost all the items, except for those regarding tourist attractions (major importance), tourist promotion materials and accommodation infrastructure (average importance each).

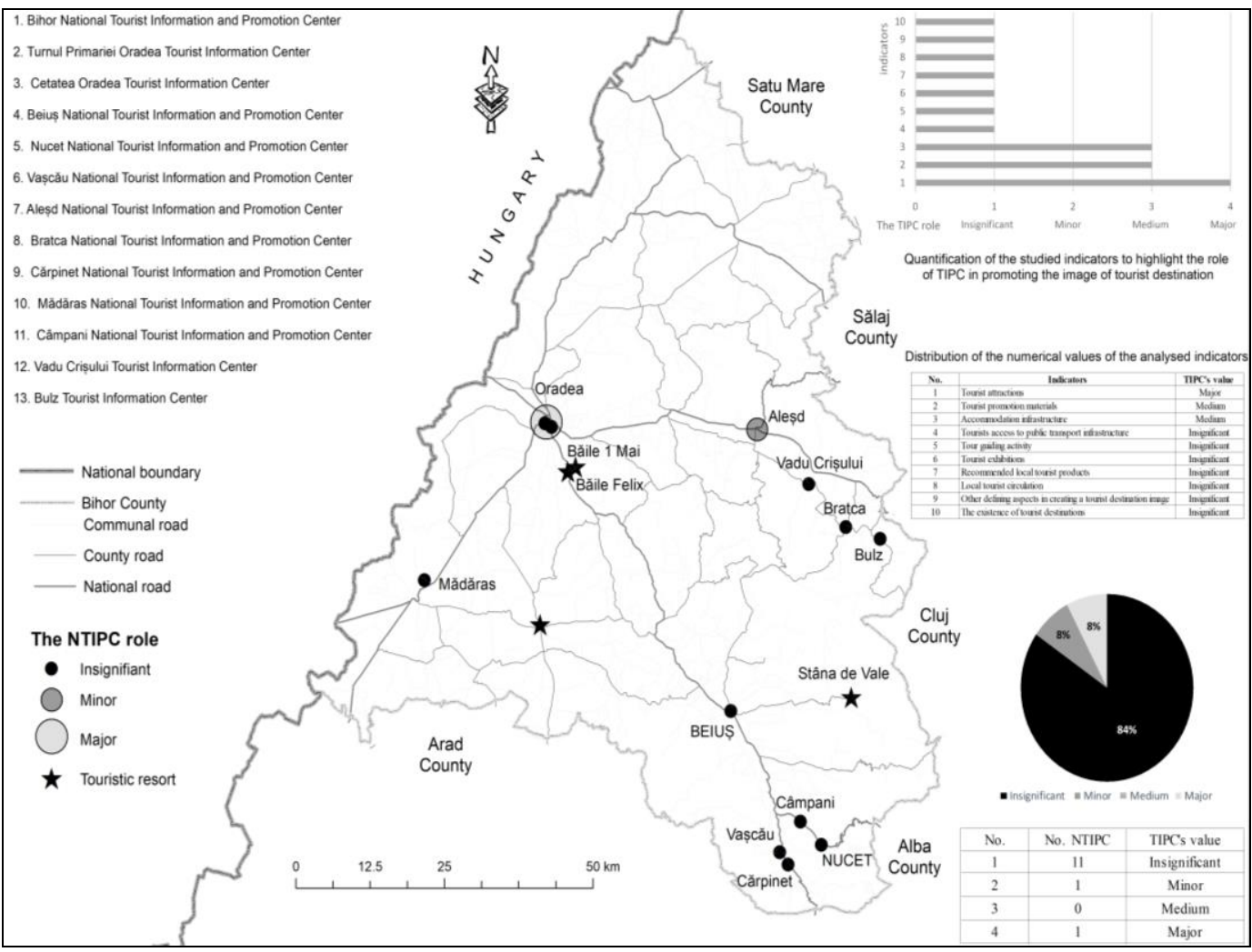

Figura 2. The TIPC role in the promotion of the tourist destination image

The TIPC in Bihor face the most serious difficulties at the chapters regarding recommended local tourist products and local tourist circulation (Table 1 and 2). Taking into account the fundamental role these entities play in the marketing strategy of the destination, the tourist information and promotion centers should possess a larger amount of information and carry out the local products marketing as well. As a result of the applied questionnaire, it is apparent that the centers face great malfunctions regarding the above mentioned responsibilities, fact that determines the limited role they have in the development of Bihor county as a tourist destination.

\section{Acknowledge}

Funded by Project 123008, „SmartDoct - High quality programs for PhD students and postdoctoral researchers at the University of Oradea to increase the relevance of research and innovation in the context of the regional economy", project funded through the Human Capital Operational Program 2014-2020. 


\section{REFERENCES}

Andrades-Caldito, L., Sánchez-Rivero, M., \& Pulido-Fernández, J. I. (2012). Differentiating Competitiveness through Tourism Image Assessment. Journal of Travel Research, 52(1), 68-81.

Andreapolou, Z., Tsekouropoulos, G., Koliouska, C., Koutroumanidis, T. (2014). Internet marketing for sustainable development and rural tourism. Int. J. of Business Information Systems, 16, 446 - 461.

Antonescu, A., \& Stock, M. (2014). Reconstructing the globalisation of tourism: A geo-historical perspective. Annals of Tourism Research, 45, 77-88.

Armenski, T., Gomezelj, D. O., Djurdjev, B., Ćurčić, N., \& Dragin, A. (2012). Tourism Destination Competitiveness-between Two Flags. Economic Research-Ekonomska Istraživanja, 25(2), 485-502.

Babbie, E. (2010). Practica cercetarii sociale. Editura Polirom, Iasi.

Bar, R., C.F. Tătar \& G.V. Herman (2016). Satisfaction degree rating of tourist services in Buziaș spa, Timiș County, Romania, GeoJournal of Tourism and Geosites, 18(2), 212-223.

Bogan, E., (2014). Communication and promotion policy in tourism marketing, International Journal of Academic Research in Environment and Geography, 1(1), 1-6;

Bryman, A. (2012). Social Research Methods, $4^{\text {th }}$ edition, Oxford University Press, USA.

Chaiprasit, K., Jariangprasert, N., Chomphunut, A., Naparat, D., \& Jaturapataraporn, J. (2011). Tourist Expectations Toward Travel And Tourism Websites In Thailand. International Business \& Economics Research Journal (IBER), 10(3), 41-50.

Chaşovschi C., Bahre H., Hildebrandt W., Maurin M. (2016). Ghid Practic. Centrele de Informare Turistică, Editura Didactică și Pedagogică, București.

Chelcea, S. (2007). Metodologia cercetărï sociologice. Metode cantitative și calitative. Editura Economică, București.

Cox, C., \& Wray, M. (2011). Best Practice Marketing for Regional Tourism Destinations. Journal of Travel \& Tourism Marketing, 28(5), 524-540.

Croes, R., \& Rivera, M. A. (2010). Testing the Empirical Link between Tourism and Competitiveness: Evidence from Puerto Rico. Tourism Economics, 16(1), 217-234.

Dahiya, A., Duggal, S., (2015). Evaluating the Official Website of SAARC Countries on their Web Information on Food Tourism, Asia Pacific Journal of Information Systems, 21(1), 145-162.

Della Corte, V., \& Aria, M. (2016). Coopetition and sustainable competitive advantage. The case of tourist destinations. Tourism Management, 54, 524-540.

Dwyer, L., Cvelbar, L. K., Mihalič, T., \& Koman, M. (2014). Integrated destination competitiveness model: testing its validity and data accessibility. Tourism analysis, 19(1), 1-17.

Fyall, A., Garrod, B., \& Wang, Y. (2012). Destination collaboration: A critical review of theoretical approaches to a multi-dimensional phenomenon. Journal of Destination Marketing \& Management, 1(1-2), 10-26.

Gómez-Vega, M., \& Picazo-Tadeo, A. J. (2019). Ranking world tourist destinations with a composite indicator of competitiveness: To weigh or not to weigh?. Tourism Management, 72, 281-291.

Gozner, M., Tătar, C.F., Stupariu, M. \& Măduta, F.M. (2017). Nature, Photography and Tourism in BihorVlădeasa Mountains (Romania). GeoJournal of Tourism and Geosites, 20(2), 210-219.

Herman, G. V., Deac, A. L., Ciobotaru, A.-M., Andronache, I. C., Loghin, V., \& Ilie, A. M. (2017). The role of tourism in local economy development. Bihor County Case Study. Urbanism Architecture Constructions 8(3), $265-274$.

Herman, G.V., Ilieș, D. C., Dumbravă, R., Wendt, J. A., \& Ilieș, A. (2019). Methodological Aspects Regarding the Quantification of the Role Of Tourism Promotion Centers in Creating the Destination Image in Romania. Études caribéennes, (43-44).

Herman, G.V., Wendt, J. A., Dumbravă, R., Gozner, M. (2019). The role and importance of promotion centers in creating the image of tourist destination: Romania. Geographia Polonica, 92(4), 443-454.

Horng, J.-S., \& (Simon) Tsai, C.-T. (2010). Government websites for promoting East Asian culinary tourism: A cross-national analysis. Tourism Management, 31(1), 74-85.

Ilies, D.C., Buhas, R., Ilies, M., Ilies, A., Gaceu, O., Pop, A.C., Marcu, F., Buhas, S.D., Gozner, M., \& Baias, S. (2018). Sport Activities and Leisure in Nature 200o Protected Area - Red Valley, Romania. Journal of Environmental Protection and Ecology, 19(1), 367-372.

Ilieș, D.C., R. Buhaș, A. Ilieș, C. Morar \& Herman, G.V. (2015). Nymphaea lotus var. Thermalis (Pârâul Peţea nature reserve), brand near extinction of the Băile Felix-Băile 1 Mai (Romania) spa tourism system, Geojournal of Tourism and Geosites, 8(1), 107-117.

Ivanov, S., \& Webster, C. (2013). Globalisation As a Driver of Destination Competitiveness. Annals of Tourism Research, 43, 628-633.

Jeong, C., Holland, S., Jun, S. H., \& Gibson, H. (2011). Enhancing destination image through travel website information. International Journal of Tourism Research, 14(1), 16-27

Kayar, Ç. H., \& Kozak, N. (2010). Measuring Destination Competitiveness: An Application of the Travel and Tourism Competitiveness Index (2007). Journal of Hospitality Marketing \& Management, 19(3), 203-216.

Khadaroo, J., \& Seetanah, B. (2008). The role of transport infrastructure in international tourism development: A gravity model approach. Tourism management, 29(5), 831-840. 
Koo, Chulmo \& Gretzel, Ulrike \& Hunter, William \& Chung, Namho. (2015). Editorial : The Role of IT in Tourism. Asia Pacific Journal of Information Systems. 25. 99-104.

Leung, X. Y., \& Baloglu, S. (2013). Tourism Competitiveness of Asia Pacific Destinations. Tourism Analysis, 18(4), 371-384.

Li, Y., Hu, C., Huang, C., \& Duan, L. (2017). The concept of smart tourism in the context of tourism information services. Tourism Management, 58, 293-300

Lincu, A., Ilieș, M., Ilieș, D.C., Herman, G.V., Baias, S., Gozner, M., Costea, M., \& Mihincău, D. (2018). Conservating the traditional cellars of Salacea, Bihor County, Romania. GeoJournal of Tourism and Geosites, 23(3), 748-758, https://doi.org/10.30892/gtg.23311-325.

Lindner-Cendrowska, K. (2013). Assessment of bioclimatic conditions in cities for tourism and recreational purposes (a Warsaw case study). Geographia Polonica, 86(1), 55-66.

Lyu, S. O., \& Hwang, J. (2015). Are the days of tourist information centers gone? Effects of the ubiquitous information environment. Tourism Management, 48, 54-63.

Mariani, M. M., Buhalis, D., Longhi, C., \& Vitouladiti, O. (2014). Managing change in tourism destinations: Key issues and current trends. Journal of Destination Marketing \& Management, 2(4), 269-272.

Mendola, D., \& Volo, S. (2017). Building composite indicators in tourism studies: Measurements and applications in tourism destination competitiveness. Tourism Management, 59, 541-553.

Molina, A., Gomez, M., Martin-Consuegra, D., (2010), Tourism marketing information and destination image management. African Journal of Business Management, 4(5), 722-728.

Paicu, C. E., Hristache, D.A., (2013). The economic and communication implications of tourism in Romania, Theoretical and Applied Economics, 20(7), 119-128.

Saarinen, J., (2001). The transformation of a tourist destination - theory and case studies on the production of local geographies in tourism in Finnish Lapland. Nordia Geographical Publications, 30(1), 1-105.

Saarinen, J., (2004). Destinations in change: The transformation process of tourist destinations. Tourist Studies, 4(2), 161-179.

Sainaghi, R., Phillips, P., \& Zavarrone, E. (2017). Performance measurement in tourism firms: A content analytical meta-approach. Tourism Management, 59, 36-56.

Shi, H., \& Li, C. (2013). Tourism Promotion, Increasing Returns and Domestic Welfare. The World Economy, 37(7), 995-1015.

Standing, C., Tang-Taye, J.-P., \& Boyer, M. (2014). The Impact of the Internet in Travel and Tourism: A Research Review 2001-2010. Journal of Travel \& Tourism Marketing, 31(1), 82-113.

Tătar, C.F., G.V. Herman \& M. Gozner (2018a). Tourist guides' contribution to sustainability in Romania, GeoJournal of Tourism and Geosites, 21(1), 282-287.

Tătar, C.F., G.V. Herman \& P. Pețan (2018b). Sport and physical activity engagement in Romania, Geosport for Society, 8(1), 40-50.

Toral, S. L., Martínez-Torres, M. R., \& Gonzalez-Rodriguez, M. R. (2018). Identification of the Unique Attributes of Tourist Destinations from Online Reviews. Journal of Travel Research, 57(7), 908-919.

Uysal, U. E. (2013). Urban Tourism Promotion: What Makes the Difference. Current Research Journal of Social Sciences, 5(1), 17-27.

Więckowski, M., Michniak, D., Bednarek-Szczepańska, M., Chrenka, B., Ira, V., Komornicki, T., ... \& Świątek, D. (2014). Road accessibility to tourist destinations of the Polish-Slovak borderland: 2010-2030 prediction and planning. Geographia Polonica, 87(1), 5-26.

*** World Economic Forum, (2017), The Travel \& Tourism Competitiveness Report 2019, Geneva, Switzerland;

*** World Economic Forum, (2019), The Travel \& Tourism Competitiveness Report 2019, Geneva, Switzerland;

*** Order 1096, 2008. Ordinul nr. 1.096 din 3 septembrie 2008 pentru aprobarea Normelor metodologice privind acreditarea centrelor naţionale de informare şi promovare turistică, http://legislatie.just.ro/Public/DetaliiDocument/97450 [5 June 2019].

*** Programul Operational Regional, http://www.old.inforegio.ro/ro/implementare/proiecte-finantate.html [30 July 2019].

*** Ministry of Regional Development and Tourism, 2012. Ministerul Dezvoltării Regionale şi Turismului, Autoritatea de Management pentru Programul Operaţional Regional. Ghidul Solicitantului, Programul Operaţional Regional 2007-2013; Axa prioritară 5 - Dezvoltarea durabilă şi promovarea turismului; Domeniul major de intervenţie 5.3 - Promovarea potenţialului turistic şi crearea infrastructurii necesare, în scopul creșterii atractivităţii României ca destinaţie turistică; Operaţiunea - Crearea Centrelor Naţionale de Informare şi Promovare Turistică (CNIPT) şi dotarea acestora.

Submitted:

22.09.2019
Revised:

23.12.2019
Accepted and published online

30.12.2019 